\title{
Morphology and dynamics of male gametogenesis in Sympterygia bonapartii (Chondrichthyes, Rajidae) from Northern Patagonia
}

\author{
Ana C. Moya; María C. Díaz Andrade \& Elena J. Galíndez
}

Laboratorio de Citología, Histología y Embriología Animal Departamento de Biología, Bioquímica y Farmacia, Universidad Nacional del Sur, San Juan 670, 8000, Bahía Blanca, Argentina - Instituto de Investigaciones Biológicas y Biomédicas del Sur - Consejo Nacional de Investigaciones Científicas y Técnicas. (mcandrade@criba.edu.ar)

\begin{abstract}
The smallnose fanskate, Sympterygia bonapartii Müller \& Henle, 1841 is one of the most disembarked items in commercial harbors in Argentina. In this work, the microscopic architecture of mature male gonads and the dynamics of cysts development are analyzed as a contribution to awareness of the reproductive biology of the species. Some biological data related to reproduction are given as well. Two seasons were sampled (fall and spring) and length classes's frequency distribution and maturity stages frequency distribution are given. Size at first sexual maturation for males was estimated at $57 \mathrm{~cm}$ of total length. Testes are symmetric, peer, lobed, with several germinal zones. Inside the gonads, there are many spermatocysts, containing reproductive cells at the same developmental stage. On the basis of their cytological and microanatomical features, several maturative degrees of the spermatogenic series were differentiated. Few Leydig cells were recognized at the interstitial tissue among cysts. The microscopic and semiquantitative analysis performed in this work provides morphological information about male gametogenesis and some biological data for the North Patagonian population of this economically and ecologically important species.
\end{abstract}

KEYWORDS. Histology, testis, smallnose fanskate, spermatogenesis.

RESUMEN. Morfología y dinámica de la gametogénesis masculina en Sympterygia bonapartii (Chondrichthyes, Rajidae) de Patagonia Norte. La raya marmorada, Sympterygia bonapartii Müller \& Henle, 1841 es una de las especies de rayas más desembarcadas en los puertos argentinos. Este trabajo analiza la dinámica y arquitectura microscópica de las gónadas de machos maduros, como una contribución para la comprensión de la biología reproductiva de esta especie. También se aportan algunos datos biológicos relacionados con la reproducción. Se tomaron muestras en dos estaciones (otoño y primavera) y se analizó la distribución de frecuencias de tallas y de estadios madurativos. Se estimó una talla de primera madurez sexual para machos de $57 \mathrm{~cm}$ de longitud total. Los testículos son pares, simétricos y lobulados, con múltiples zonas germinales. Dentro de los lóbulos hay espermatocistos, cada uno de los cuales contiene células sexuales en el mismo estadio de desarrollo. Se diferenciaron diversos grados madurativos de la serie espermatogénica, en base a sus características citológicas y microanatómicas. En el tejido intersticial, entre los cistos, se encontraron células de Leydig. Los análisis microscópico y semicuantitativo llevados a cabo en este trabajo proveen información morfológica sobre la gametogénesis masculina y algunos datos de la biología reproductiva de esta población del norte de la Patagonia.

PALABRAS CLAVE. Histología, testículo, raya marmorada, espermatogénesis.

Chondrichthyes constitute a successful group with a long and intricate evolutionary history (NAYLOR et al., 2005), based mainly on the diversity of reproductive modes that they exhibit, quite different from those of teleost (HAMLETT, 1999). The reproductive strategies vary from the exclusive lecitotrophism, to several degrees of matrotrophism (MusicK \& Ellis, 2005; GaLíndeZ et al., 2010). On the other hand, this clade is characterized by a low growth, an extensive period of gestation and a scarce number of large offspring, all this resulting in a low reproductive potential that makes this fish highly vulnerable to overfishing (Dulvy et al., 2008). As a consequence of this, chondrichthyan fisheries have been strongly disturbed around the world (WARD PAIGE et al., 2012). For instance, in Argentina the increase in the Chondrichthyes exploitation has been resulting in a decline of stocks for the last 20 years (TAMINI et al., 2006; MASSA \& HozBOR, 2011).

The genus Sympterygia is endemic of the Southwest Atlantic (Cousseau et al., 2000; Menni \& Stehmann, 2000). The smallnose fanskate, Sympterygia bonapartii Müller \& Henle, 1841, extends from State of Rio Grande do Sul, in Brazil, to the Estrecho de Magallanes, Argentina (FigueIREDO, 1977; Massa et al., 2004). It is a relatively medium-size skate, present longwise in the coastline of Argentina. This species is oviparous and uses mainly the estuarine waters for mating, giving birth and as a breeding ground (MabragaÑa et al., 2002; López Cazorla, 2007). In Argentina, is one of the most disembarked item in the commercial harbors (MASSA \& HozBor, 2011) and according to the paucity in the complete knowledge of their reproductive features, the IUCN Red List for threatened species (INTERNATIONAL UNION FOR THE CONSERVATION of Nature and Nature Resources, 2014) considers $S$. bonapartii as "insufficient data for evaluation". In spite of the economic and ecological importance of this species and the vulnerability of its actual situation, there are few reports about morphofunctional aspects of its reproduction.

The aim of this work is to analyze the morphology of the sexually active male gonads and the dynamics of cysts development in $S$. bonapartii, as well as providing some biological parameters of the species in a population of the Northern Patagonia.

\section{MATERIALS AND METHODS}

This study was performed on the population of $S$. 
bonapartii inhabiting the Bahía Blanca estuary $\left(61^{\circ} 30^{\prime}\right.$ $62^{\circ} 30^{\prime} \mathrm{O}$ y $38^{\circ} 45^{\prime}-39^{\circ} 20^{\prime} \mathrm{S}$ ). Specimens were obtained from two different sources: for morphologic study, a total of 20 sexually active males of $S$. bonapartii were collected monthly during spring and fall (March, April, May, October and November) by line fishing. For biological analysis, 212 animals were also gathered during spring and autumn (March, April, May, September, October and November) from artisanal fishery landings, and sampled at Roucomar Fish Processing Plant (Ingeniero White harbour, Bahía Blanca, Argentina).

The sexual maturation stage of fish was classified as immature, maturing and mature according to criteria of SteHMANN (2002), based on the macroscopic aspect of claspers and internal reproductive organs. This classification was also corroborated considering the histological grade of development of the testis (Fig. 1). Total length and disc width were measured at lesser millimeter, as well as the clasper length, from the insertion below the pelvic fin to its end, according the Compagno (1984) criteria. Gonad weight $(\mathrm{Wg})$ was recorded to the nearest $0.1 \mathrm{~g}$ for specimens from the artisanal fishery. To determinate size at first sexual maturation, a logistic ogive was fitted to the data of maturity proportions on each length classes, using a maximum-likehood approach (AUBONE \& WÖHLER, 2000). The symmetry in gonads weight and claspers length was analyzed using a Student's "t" statistical test.

Each animal collected for histological study was sacrificed on board by a concussion, according to the protocol approved by the Comite Institucional para el Cuidado y Uso de Animales de Experimentación, Departamento de Biología, Bioquímica y Farmacia, Universidad Nacional del Sur (Protocol ${ }^{\circ}$ 022/2014). The dissection of the reproductive system was carried out and small pieces of the gonads were fixed in Bouin's solution in seawater for at least 24 hours. Afterwards, all material was dehydrated through a graded series of alcohols and embedded in Paraplast ${ }^{\circledR}$. Sections of 5-6 $\mu$ m thick were stained by Masson's trichromic stain and hematoxylineosin. For cell and cyst microscopic measurements, a micrometric ocular with 0.1 micrometer accuracy was used. A medium value and the standard deviation were estimated for each parameter. Selected sections were photographed using an Olympus BX51 light microscope equipped with an Olympus C-7070 digital camera. To determine the coverage of spermatogenic stages, one lobe of the medial region of each gonad was employed to delineate every gametogenic area and thus determine their significance. The analysis was made from dorsal to ventral sides of the testis and employing UTHSCSA ImageTool V. 3.0

\section{RESULTS}

A total of 212 males from the artisanal fishery landings, were analyzed. The length classes's frequency distribution indicates that bigger males are more abundant in

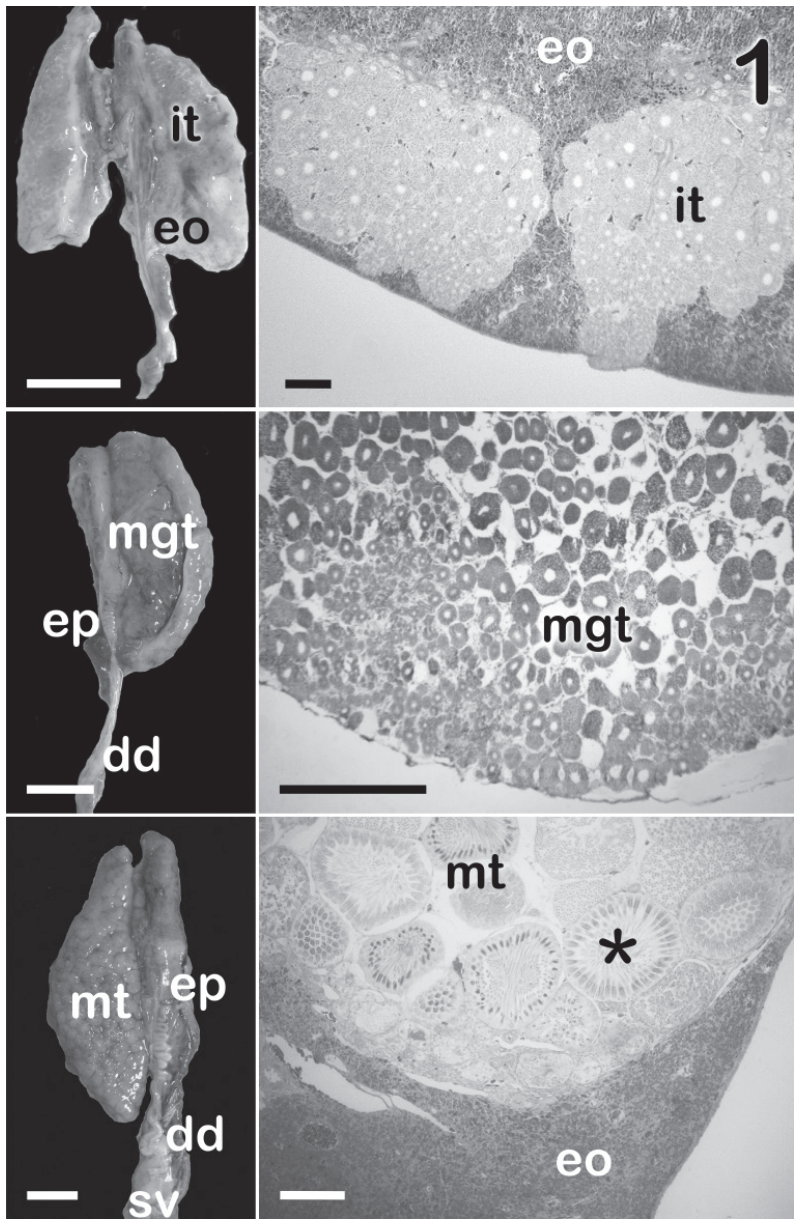

Fig. 1. General aspect of the male reproductive organs of Sympterygia bonapartii Müller \& Henle, 1841 according to the sexual maturation stage (left) and the corresponding microscopic aspect of the testes (right) (it, immature testis; eo, epigonal organ; mgt, maturing testis; ep, epididymis; $\mathrm{mt}$, mature testis; dd, deferent duct; sv, seminal vesicle; asterisk depicts a mature cyst). Left scale bars, $1.5 \mathrm{~cm}$; right scale bars, $200 \mu \mathrm{m}$. Masson's trichromic stain.

spring (Fig. 2), while the seasonal maturity stages frequency distribution shows a prevail of immature exemplars in autumn and of maturing ones in spring (Fig. 3). The largest immature male was $55 \mathrm{~cm} \mathrm{LT}$, the largest maturing one was $66.5 \mathrm{~cm}$ LT and the smallest mature male was $54 \mathrm{~cm}$ LT. Size at first sexual maturation was estimated as $57 \mathrm{~cm}$, corresponding to the $79 \%$ of the maximum total length observed in males.

In $S$. bonapartii the male reproductive system is located in the abdominal cavity, in a dorsal position with respect to the digestive organs and liver. The internal reproductive organs encompass: the testis, the efferent ducts, the epididymis, the deferens ducts, the seminal vesicles and the Leydig glands (Fig. 1). Testes are pair, lobed and dorsoventrally flattened organs, enveloped by the epigonal organ, a yellowish lymphomyeloid tissue. There were no statistical differences between left and right testes weight (Student's t test, $\mathrm{p}=0.46$ ), as well as in the clasper's length (Student's $t$ test, $\mathrm{p}=0.95$ ).

Testes are lined by a simple squamous to cuboidal 

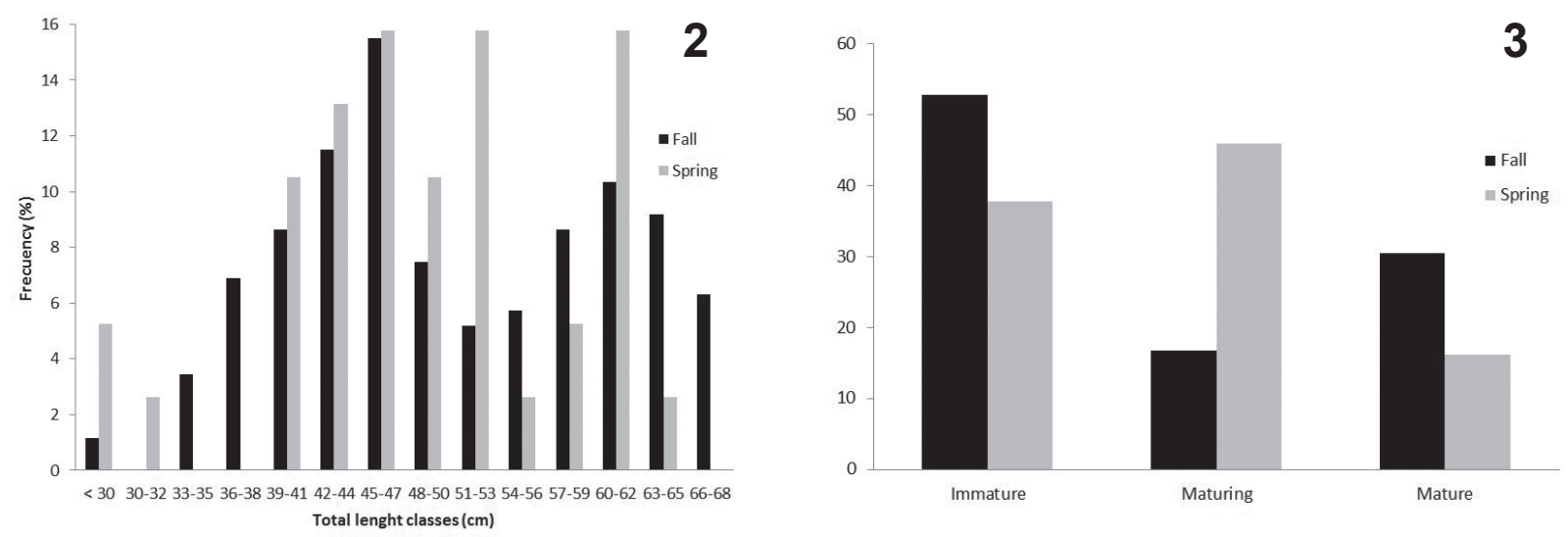

Figs 2, 3. Fig. 2, length class frequency distribution of Sympterygia bonapartii Müller \& Henle, 1841 males on fall (March, April and May) and spring (September, October and November) at Bahía Blanca estuary, Argentina; Fig. 3, maturity stages frequency distribution of Sympterygia bonapartii Müller \& Henle, 1841 males on fall (March, April and May) and spring (September, October and November) at Bahía Blanca estuary, Argentina.

epithelium and a thin layer of dense connective tissue (Fig. 4). This capsule emits vascular trabeculae that define lobes. In this connective tissue, there is also evidence of the start of the duct system. The lymphomyeloid tissue is represented by a small outline at the posterior surface of the testes (Fig. 5).

Both testes include multiple lobules, each one of them showing the complete spermatogenic series (Fig. 5). The differentiation of sperm takes place within spermatocysts. These are spherical structures defined by a basement membrane and lined by a germinal epithelium formed by Sertoli and spermatogenic cells. The testicular parenchyma of sexually active skates comprises an aggregate of spermatocysts embedded in a loose connective matrix that includes blood vessels and Leydig cells. New spermatocyst are formed in a germinal zone, located at the dorsal surface of the lobe. As new spermatocysts are formed, the oldest displace diametrically throughout the lobe, like an "open fan” (Fig. 5).

According the spermatogenic wave progress, germ cells depict not only different cytological features but also a distinctive arrangement within the cyst. On the basis of these characteristics, it is possible to distinguish seven kinds of spermatocysts.

The morphometric characteristics of germ cells are shown in Table I, while Table II shows the average coverage of spermatogenic stages within the testicular lobes, in each sampled season. Figure 6 depicts the average diameter of cysts at the different testicular zones.

Spermatocysts of the Germinal Zone. The germinal zone is a restricted dorsal area where spermatogenesis initiates (Fig. 7). Spermatogenic process initiates with the spermatogonium, which is distinguished as a rounded cell with large euchromatic nucleus, containing patches of heterochromatin (Fig. 8). Spermatogonia are associated with few Sertoli cells, which are medium sized cells, with a lightly eosinophilic and irregular cytoplasm and an ovalshaped heterochromatic nucleus containing 2-3 nucleoli. At this point, the deposition of the basement membrane, that will define the cyst, initiates. These primary spermatogonia cysts are small, massive acinar-like structures.

Spermatocysts with spermatogonia. Once completely enveloped by the basement membrane, the cysts are clearly defined. Initially they are formed by a single layer of spermatogonia and Sertoli cells surrounding an incipient lumen (Fig. 8). Cells proliferate and the cyst wall becomes stratified. Spermatogonia are more abundant than Sertoli cells so that they push the Sertoli cell nucleus toward the lumen (Fig. 9). When cyst acquires several layers, the nucleus of the Sertoli cells become located at their definitive position, adjacent to the basement membrane. At this point the lumen is still present.

Spermatocysts with spermatocytes. As spermatogonia proliferate and differentiate into spermatocytes, the cysts increase in size (Fig. 10). Primary spermatocytes are rounded, large cells with the distinctive chromatin pattern of the first meiotic division. These cells result in secondary spermatocytes (Fig. 11), which are smaller than primary ones, with heterochromatic nucleus. Sertoli cells dispose abutted to the basement membrane and the lumen occludes gradually.

Spermatocysts with spermatids. The second meiotic division leads to spermatids. The most immature cysts are plenty of small cells with a round heterochromatic nucleus that fill the entire cyst (Fig. 12). On the other hand, the most mature spermatids are elongated with a filiform and heterochromatic nucleus. These cells arrange gradually in loose and peripheral bundles, partially embedded in the apical cytoplasm of Sertoli cells, defining a lumen in the cyst (Fig. 13). Between these two extremes, a range of intermediate cell morphologies can be observed.

Spermatocysts with immature sperm. Immature sperm cells characterize by their lengthened shape and the high degree of chromatin condensation. They are organized in bundles attached to Sertoli cells at the periphery of the cyst (Fig. 14).

Spermatocysts with mature sperm. At this stage, sperm cells complete their differentiation and organize 
Tab. I. Size and nuclear dimensions of maturative spermatogenic cells at the mature testis of Sympterygia bonapartii Müller \& Henle, 1841 from Bahía Blanca estuary, Argentina (ND, not determined)

\begin{tabular}{lcc}
\hline Cell type & Cell size $(\mu \mathrm{m})$ & Nuclear diameter $(\mu \mathrm{m})$ \\
\hline Spermatogonia & $12.00-15.00$ & $7.00-10.00$ \\
Primary spermatocytes & $5.00-12.50$ & $3.75-7.50$ \\
Secondary spermatocytes & $4.00-7.50$ & $2.50-3.75$ \\
Spermatids & $2.50-3.75$ & $1.50-2.50$ \\
Immature sperm & ND & $12.5-15.00($ head) \\
Mature sperm & $30.00-40.00$ (tail length) & $15.00-20.00($ head) \\
\hline
\end{tabular}

Tab. II. Average coverage, in percentage, of each lobule zone during spring (September, October and November) and fall (March, April and May) at the mature testis of Sympterygia bonapartii Müller \& Henle, 1841 from Bahía Blanca estuary, Argentina.

\begin{tabular}{lcc}
\hline \multirow{2}{*}{ Lobule zone } & \multicolumn{2}{c}{ Average } \\
\cline { 2 - 3 } & Spring & Fall \\
\hline Spermatocysts of the Germinal zone & 1.2 & 0.5 \\
Spermatocysts with spermatogonia & 10.3 & 15 \\
Spermatocysts with spermatocytes (primary and secondary) & 28.5 & 12.8 \\
\hline Spermatocysts with spermatids & 16.6 & 30.8 \\
Spermatocysts with immature and mature sperm & 10.6 & 18.6 \\
Degenerate zone & 32.8 & 22.3 \\
\hline
\end{tabular}
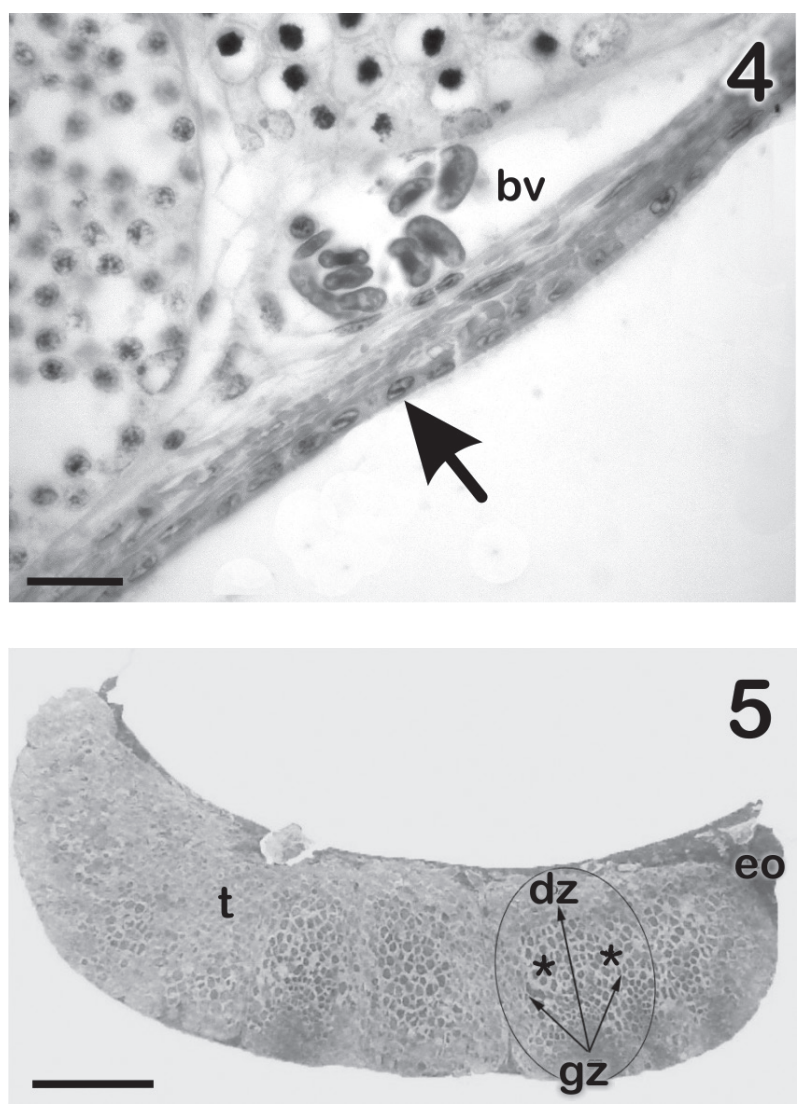

Figs 4, 5, Sympterygia bonapartii Müller \& Henle, 1841. Fig. 4, medium magnification of the testicular surface. Arrow shows the cuboidal lining epithelium (bv, blood vessel). Scale bar, $15 \mu \mathrm{m}$. Masson's trichromic stain. Fig. 5, general view of a cross section of the testis. Oval indicates one testicular lobe and the arrows point the maturative wave direction (t, testis; gz, germinal zone; dz, degeneration zone; eo, epigonal organ). Asterisks point to the cysts. Scale bar, $0.5 \mathrm{~cm}$. Masson's trichromic stain.

in tight packages, embedded in the apical cytoplasm of Sertoli cells. Their spiral-shaped tails are arranged toward the lumen. At this point, cysts occupy the periphery of the lobe (Fig. 15).

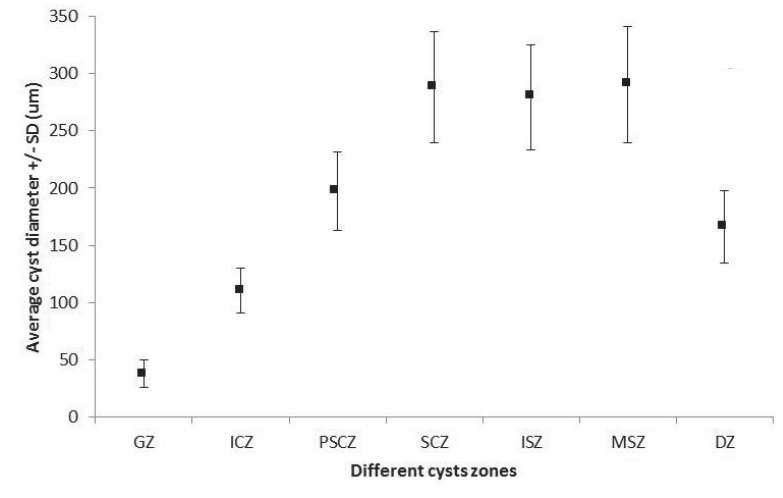

Fig. 6. Average diameter and standard deviation of the cysts from different testicular zones of mature males of Sympterygia bonapartii Müller \& Henle, 1841 at Bahía Blanca estuary, Argentina (GZ, germinal zone; $\mathrm{SgCZ}$, spermatogonia cysts zone; PSSCZ, primary and secondary cysts zone; SCZ, spermatid cysts zone; ISZ, immature sperm cysts zone; MSZ, mature sperm cysts zone; DZ, degenerate zone).

Degenerate zone. This area is composed by spermatocysts plenty of cellular debris or with few degenerating cells (Fig. 16).

Interspersed in the interstitial connective tissue, there are some cells depicting a large, round nucleus with a thick peripheral heterochromatin ring and scarce acidophilic cytoplasm. These features are consistent with Leydig cells. These cells are more abundant in the zone of the lobe where cysts with spermatids and sperm are present (Fig. 17).

\section{DISCUSSION}

The criteria usually employed to quickly determine the stage of sexual maturity in chondrichthyan males is the length and hardening of claspers. DíAz ANDRADE et al. (2010) determined that clasper elongation in immature males of $S$. bonapartii is exponential, meanwhile mature males show a linear pattern of clasper growth, so that clasper elongation would be the first morphologic event 

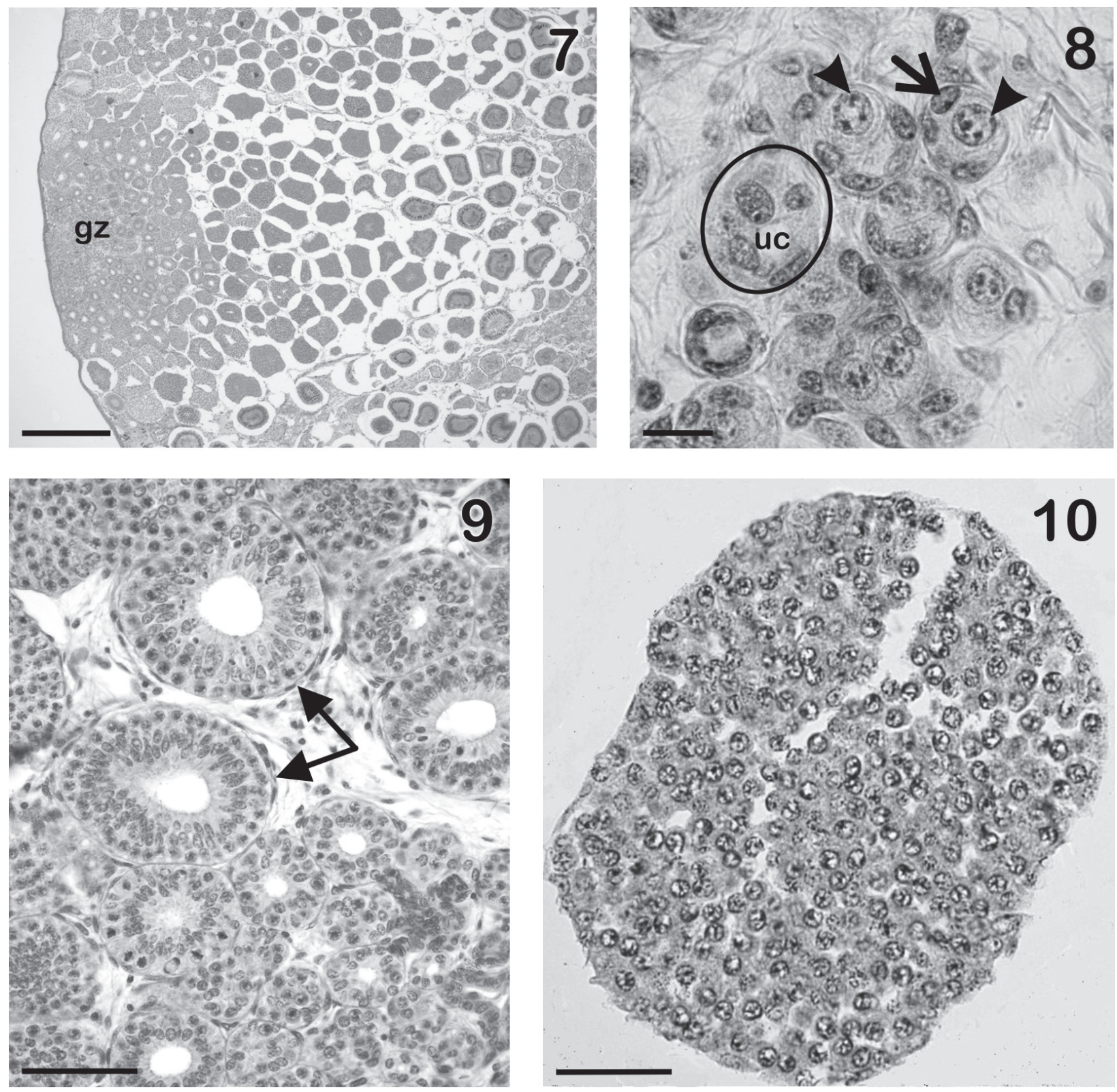

Figs 7-10, Sympterygia bonapartii Müller \& Henle, 1841. Fig. 7, low magnification of a testicular lobe showing the zonation of the parenchyma (gz, germinal zone). Scale bar, $400 \mu \mathrm{m}$. Masson's trichromic stain. Fig. 8, high magnification of the germinal zone at the mature testis. Arrowheads indicate spermatogonia, while arrow points to the nucleus of Sertoli cell. Oval shows a unilayer cyst (uc). Scale bar, $12.5 \mu \mathrm{m}$. Masson's trichromic stain. Fig. 9, multilayer cysts with spermatogonia at the mature testis. Arrow indicates cysts. Scale bar, $50 \mu \mathrm{m}$. Masson's trichromic stain. Fig. 10, spermatocyst containing primary spermatocytes at the mature testis. Scale bar, $50 \mu \mathrm{m}$. Masson's trichromic stain.

in male maturation, followed by clasper calcification and the development of alar thorns (MABRAGAÑa et al., 2002). Our results show that the length and hardening of the claspers are not only related to the macroscopic aspect of the genital organs, but it also agrees with the histological events (spermatogenesis and spermiogenesis) that occur inside the testis, thus sustaining the conception that length growth and hardening of the claspers are a valid and simple criteria to determine maturity on board, at least for $S$. bonapartii.

The size range observed in S. bonapartii is consistent with those reported by other authors for the same species
(Mabragaña et al., 2002; Oddone \& Velasco, 2004; Cousseau et al., 2007; Jañez \& Sueiro, 2007; Basallo $\&$ OdDone, 2014). Likewise, the seasonal frequency of maturity stages here observed, does not differ from previous reports regarding to $S$. bonapartii for the El Rincón salt marsh area, near the Bahía Blanca estuary (MABRAGAÑA et al., 2002).

There are some references regarding the size at maturity for the smallnose fanskate. OdDONE \& Velasco (2004) calculated that the size at first sexual maturation was in the range between 52 and $57 \mathrm{~cm}$ or males inhabiting the South of Brazil, while BASALlo \& OdDONE (2014) 

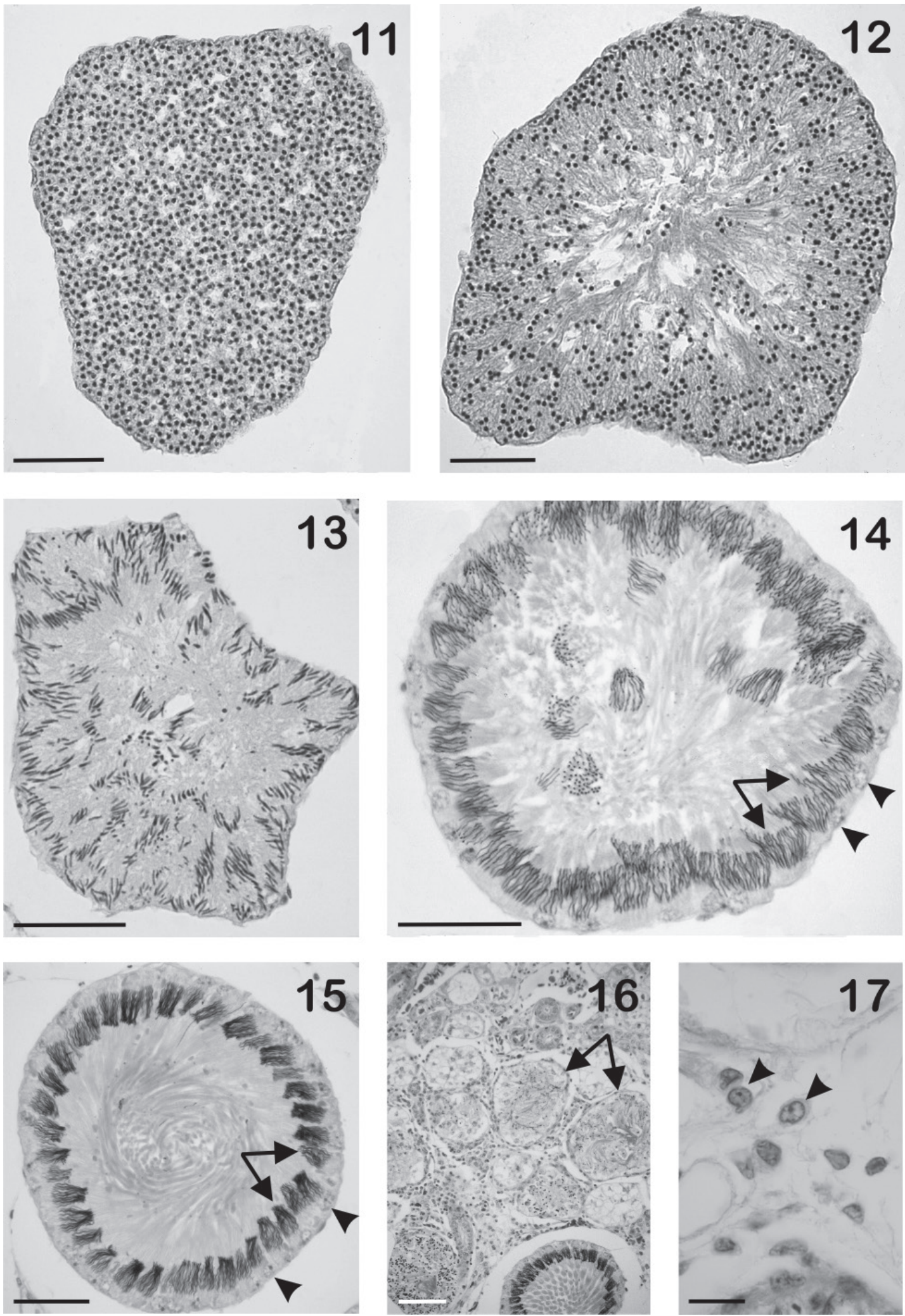

Figs 11-17, Sympterygia bonapartii Müller \& Henle, 1841. Fig. 11, low magnification image of spermatocyst containing secondary spermatocytes at the mature testis. Scale bar, $50 \mu \mathrm{m}$. Masson's trichromic stain. Fig. 12, Spermatocyst with immature spermatids at the mature testis. Note the incipient lumen. Scale bar, $50 \mu \mathrm{m}$. Masson's trichromic stain. Fig. 13, spermatocyst with mature spermatids at the mature testis. Scale bar, 50 $\mu \mathrm{m}$. Mason's trichromic stain. Fig. 14, immature sperm at the mature testis. Note the loose bundles of immature sperm forming patches (arrows). Arrowheads indicate the nucleus of Sertoli cells. Scale bar, $70 \mu \mathrm{m}$. Masson's trichromic stain. Fig. 15, mature sperm at the mature testis. The well-defined cyst shows discrete packages of sperm (arrows). Arrowheads indicate the nucleus of Sertoli cells. Scale bar, $75 \mu \mathrm{m}$. Masson's trichromic stain. Fig. 16, degenerate zone at the mature testis. Arrows show spermatocysts with cellular debris. Scale bar, $200 \mu \mathrm{m}$. Masson's trichromic stain. Fig. 17, high magnification of the interstitial tissue between cysts at the mature testis. Arrowheads point to Leydig cells. Scale bar, $15 \mu$ m. Hematoxylin-eosin stain. 
determined it was $58 \mathrm{~cm}$ for the same population. On the other hand, MaBragaña et al. (2002) estimated that the size at maturity for males inhabiting Uruguay and the north coast of Argentina, was about $65 \mathrm{~cm}$. The size at first sexual maturation calculated in this work is within the ranges established by ODDONE \& VELASCO (2004) and BASALLO \& ODDONE (2014) but is clearly below the size reported by Mabragaña et al. (2002). Even though this could indicate that the population is exposed to some anthropic pressure, it could exist other biological or environmental factors that could be affecting this fish population locally.

The anatomical structure of the male reproductive system of $S$. bonapartii agrees with the observed on most Batoids (WALKER, 2005). Likewise, the symmetry found in claspers length and gonadal weight, has also been observed on other Chondrichthyes, including the Rajidae (SULIKOWSKi et al., 2005).

In sexually active individuals, sperm production is a complex, highly organized and coordinated process, involving morphologic and functional interactions between germ cells and some types of somatic cells and their secretions (PIERANTONI et al., 2009). In cartilaginous fish, the successive stages of spermatogenesis are arranged in a strict temporal and spatial order, constituting a cystic testicular pattern of organization. This model is clearly different from the seminiferous tubule pattern, and depicts a distinctive model of annamiontes (BATLOUNI et al., 2009). According to GRIER (1993), the continue renewing of both, germinal and Sertoli cells, occurs in each successive spermatogenic cycle or breeding season, and cysts degenerate after spermiation, and this seems to be the case for $S$. bonapartii.

Spermatocyst constitute the structural and functional unity of Chondrichthyes male gonads (WALKER, 2005). The production and maturation of spermatocysts in the "cystic testicle" of Chondrichthyes may follow different patterns. In the smallnose fanskate, this progression involves the migration of maturing cysts draw away radially from the germinal zone, and throughout the testis diameter. This model agrees to the "testicular compound model" defined by PRATT (1988) and is also present in other skates and rays. This organization pattern could be interpreted as an adaptation to the "flattened" body of these fish.

PARSONS \& GRIER (1992) have analyzed the changes in spermatocysts diameter of Sphyrna tiburo (Linnaeus, 1758), and reported that there was an increase in diameter until the stage of cysts containing secondary spermatocytes. However, in S. bonapartii there was an increase in diameter until the cysts with spermatids, which are the largest ones. Therefore, the cysts where the process of spermiogenesis occurs present a constant diameter. These specific differences could be associated to different testicular models.

Our data show that, in both seasons, the most represented cystic developmental stage, according to its coverage, was that in which spermiogenesis occurs. Even though, the observations made in this study correspond only to two seasons, these are in agreement with PARSONS \& GRIER (1992). These authors stated that the definition of the testicular coverage of each stage is a useful tool to determine a seasonal cycle of activity in this group of fish, especially when these data are correlated with mating activity observations and gonadosomatic indexes.

The cytological general features of the spermatogenesis in the smallnose fanskate are consistent with that seen from cyclostomes to mammals (HAMLET, 1999). The association of very immature cysts forming a dorsal "germinal papilla" is common in other Chondrichthyes (StAnley, 1966; MarusKa et al., 1996; ChatchaVAlanich et al., 2004). However, this papilla is absent in S. bonapartii.

The spermiogenesis process can show many variations among different taxa. GIRARD et al. (2000) reported three different types of spermatids in sharks, based on the nuclear shape: immature spermatids with small round nuclei, intermediate spermatids with pyriform nuclei and mature spermatids with large oval nuclei. Despite this classification, spermiogenesis is a continuous and complex process that involves, among other things, the condensation of chromatin, elongation of the nucleus, the loss of much of cytoplasm and assembly of the flagellum. Taking this into account, it is not rare to find a wide range of cellular morphologies.

The presence of a degenerate zone exhibits a great variation among chondrichthyan species. TESHIMA (1981) has not reported a degenerate zone either in Mustelus manazo (Bleeker, 1854) and M. griseus (Pietschmann, 1908). However, SiMPSON \& WARDLE (1967) and SUMPTER $\&$ DooD (1979) reported some variations on the localization of the degenerate zone according to the season in Squalus acanthias (Linnaeus, 1758) and Scyliorhinus canicula (Linnaeus, 1758), respectively. By the contrary, the data exposed here show no differences at the degenerate zone localization among seasons. However, the coverage area of this zone was larger during spring, suggesting that males release more sperm during this season. MABRAGAÑA et al. (2002) observed that gonadosomatic index and diameter of ovarian follicles of mature females of $S$. bonapartii peaked in late spring and also found females carrying egg cases during late spring on shallow waters. These observations are consistent with the data exposed in this work, and sustain the hypothesis that the smallnose fanskate exhibits a short reproductive season in temperate shallow-waters as a strategy to guarantee that the deposition of egg-cases and growth of neonates takes place in well-protected nursery areas.

In the last years, the histological tools have been recognized as crucial for reproductive studies, allowing improvements in the efficacy of management options (AlOnso Fernández et al., 2011). Usually, biological and morphological studies on fish reproduction have focused on female's gonad and males have been often considered of less importance for this point of view. However, the results of this work show that a morphological approach 
to male reproduction can offer such valuable information as females.

The microscopic analysis performed in the testes of $S$. bonapartii in this work, provides not only a more accurate information on the male gonad morphology and dynamics, but also has proved to be a complementary approach that may contribute to a better knowledge and care of this important species.

Acknowledgements. We thank Prefectura Naval Bahía Blanca and Roucomar processing plant for their help in samplings. This work was supported by the SGC y T-UNS, PGI 24/B173.

\section{REFERENCES}

Alonso Fernández, A.; Alós, J.; Grau, A.; Domínguez Petit, R. \& SABORIDO ReY, F. 2011. The use of histological techniques to study the reproductive biology of the hermaphroditic mediterranean fishes Coris julis, Serranus scriba and Diplodus annularis. Marine and Coastal Fisheries: Dynamics, Management and Ecosystem Science 3:145-159.

Aubone, A. \& WöHLER, O. C. 2000. INIDEP Informe Técnico Vol. 37. Aplicación del método de máxima verosimilitud a la estimación de parámetros y comparación de curvas de crecimiento de von Bertalanffy. Mar del Plata, Instituto Nacional de Investigación y Desarrollo Pesquero. 21p.

Basallo, A. \& Oddone, M. C. 2014. Reproductive biology of the skates Sympterygia acuta Garman, 1877 and S. bonapartii Müller \& Henle, 1841 (Chondrichthyes: Rajoidei) in south Brazil. Neotropical Ichthyology 12(4):771-782.

Batlouni, S. R.; Nóbrega, R. H. \& FrançA, L. R. 2009. Cell junctions in fish seminiferous epithelium. Fish Physiology and Biochemistry 35:207-217.

Chatchavalvanich, K.; Thongpan, A. \& Masaaki, N. 2004. Structure of the testis and genital duct of freshwater stingray, Himantura signifier (Elasmobranchii: Myliobatiformes: Dasyatidae). Ichthyological Research 52:123-131.

Compagno, L. J. V. 1984. FAO species catalogue. Sharks of the world: an annotated and illustrated catalogue of sharks species known to data. Part 2, Carcharhiniformes. FAO Fisheries Synopsys 125:251-655.

Cousseau, M. B.; Figueroa, D. E. \& Díaz de Astarloa, J. M. 2000. Clave de Identificación de las Rayas del Litoral Marítimo de Argentina y Uruguay (Chondrichthyes, Familia Rajidae). Mar del Plata, Instituto Nacional de Investigación y Desarrollo Pesquero. 35p.

Cousseau, M. B.; Figueroa, D. E.; Díaz de Astarloa, J. M.; Mabragaña, E. \& LUCIFORA, L. O. 2007. Rayas, chuchos y otros batoideos del Atlántico Sudoccidental $\left(34^{\circ} \mathrm{S}-\mathbf{5 5}^{\circ} \mathrm{S}\right)$. Mar del Plata, Instituto Nacional de Investigación y Desarrollo Pesquero. 102p.

Díaz Andrade, M. C.; Moya, A. C.; Galíndez, E. J.; Lopez Cazorla, A. \& EsteCondo, S. 2010. Dynamics of growth and development of claspers in Sympterygia bonapartii (Chondrichthyes; Rajidae) from the Bahia Blanca estuary. Ciencias Morfológicas 12:20.

Dulvy, N. K.; Baum, J. K.; Clarke, S.; Compagno, L. J. V.; Cortes, E.; Domingo, A.; Fordham, S.; Fowler, S.; Fracis, M. P.; Gibson, C.; Martinez, J.; Musick, J. A.; Soldo, A.; Stevens, J. S. \& VALENTI, S. 2008. You can swim but you can't hide: the global status and conservation of oceanic pelagic sharks and rays. Aquatic Conservation: Marine and Freshwater Ecosystems 18:459-482.

Figueiredo, J. L. 1977. Manual de Peixes Marinhos do Sudeste do Brasil. I. Introdução, Cações, Raias e Quimeras. São Paulo, Museu de Zoologia da Universidade São Paulo. 104p.

Galíndez, E.; Díaz Andrade, M. C.; Moya, A. C. \& Estecondo, S. 2010. Morphological changes in the pregnant uterus of the smooth hound dogfish Mustelus schmitti Springer, 1939 (Gatuzo) (Chondrichthyes, Triakidae). Microscopic study and phylogenetic reproductive implications. International Journal of Morphology 28:1003-1010

Girard, M.; Rivalan, P. \& Sinquin, G. 2000. Testis and sperm morphology in two deep-water squaloid sharks, Centroscymnus coelolepis and Centrophorus squamosus. Journal of Fish Biology 57:1575-1589.
Grier, H. J. 1993. Comparative organization of Sertoli cell barrier. In: Russell, L. D. \& GRISwOLD, M. D. eds. The Sertoli cell. Clearwater, Cache River Press, p.704-730.

Hamlett, W. C. 1999. Sharks, Skates and Rays: the biology of Elasmobranch Fishes. Baltimore, The Johns Hopkins University Press. 515p.

INTERNATIONAL UNiON FOR the CONSERVATION OF NATURE AND NATURE RESOURCES. 2014. IUCN Red List of threatened species. Available at $<$ http://www.iucnredlist.org $>$. Accessed on 10.07.2015.

JAÑEZ, J. A. \& SueIro, M. C. 2007. Size at hatching and incubation period of Sympterygia bonapartii (Müller \& Henle, 1841) (Chondrichthyes, Rajidae) bred in captivity at the Temaiken Aquarium. Journal of Fish Biology 70:648-650.

López Cazorla, A. 2007. Peces. In: Piccolo, M. C. \& Hoffemeyer, M. S. eds. Ecosistema del estuario de Bahía Blanca. 3ed. Bahía Blanca, Instituto Argentino de Oceanografía, p.191-201.

MabragaÑa, E.; Lucifora, L. O. \& Massa, A. M. 2002. The reproductive ecology and abundance of Sympterygia bonapartii endemic to the south-west Atlantic. Journal of Fish Biology 60:951-967.

Maruska, K. P.; Cowie, E. G. \& Tricas, T. C. 1996. Periodic gonadal activity and protracted mating in elasmobranch fishes. Journal of Experimental Zoology 276:219-232.

Massa, A. \& Hozbor, N. M. 2011. Evolución de las estimaciones de abundancia de los peces cartilaginosos de mayor valor comercial del Atlántico Sudoccidental, capturados entre $34^{\circ}$ y $41^{\circ} \mathrm{S}$, a profundidades menores de 50 m. In: Wohler, O. C.; Cedrola, P. \& Cousseau, M. B. eds. Contribuciones sobre biología, pesca y comercialización de tiburones en la Argentina. Aportes para la elaboración del Plan de Acción Nacional. Buenos Aires, Consejo Federal Pesquero, p.193-205.

MasSA, A. M.; Hozbor, N. \& Colonello, J. 2004. INIDEP Informe Técnico 57: Situación actual y avances en el estudio de los peces cartilaginosos. Mar del Plata, Instituto Nacional de Investigación y Desarrollo Pesquero. 18p.

Menni, R. C. \& Stehmann, M. F. W. 2000. Distribution, environment and biology of batoids fishes of Argentina, Uruguay and Brazil. A review. Revista del Museo de Ciencias Naturales 2:69-109.

Musick, J. A. \& Ellis, J. K. 2005. Reproductive evolution of Chondrichthyans. In: НAMLETT, W. C. ed. Reproductive Biology and Phylogeny of Chondrichthyes. Sharks, Batoids and Chimeras. Enfield, Science Publishers, p.45-79.

Naylor, G. J. P.; Ryburn, J. A.; Fedrigo, O. \& Lopez, A. 2005. Phylogenetic relationships among the major lineages of modern Elasmobranchs. In: HAMLETT, W. C. ed. Reproductive Biology and Phylogeny of Chondrichthyes. Sharks, Batoids and Chimeras. Enfield, Science Publishers, p.2-25.

Oddone, M. C. \& Velasco, G. 2004. Size at maturity of the smallnose fanskate Sympterygia bonapartii (Müller \& Henle, 1841) (Pisces, Elasmobranchii, Rajidae) in the SW Atlantic. ICES. Journal of Marine Science 61:293-296.

PARsons, G. R. \& GRIER, H. J. 1992. Seasonal changes in shark testicular structure and spermatogenesis. Journal of Experimental Zoology 261:173-184

Pierantoni, R.; Cobellis, G.; Meccariello, R.; Cacciola, G.; Chianese, R.; ChiocCarelli, T. \& Fasano, S. 2009. Testicular gonadotropinreleasing hormone activity, progression of spermatogenesis, and sperm transport in vertebrates. Trends in Comparative Endocrinology and Neurobiology: Annals of the New York Academy of Sciences 1163:279-291.

Pratt, H. L. 1988. Elasmobranch gonad structure: a description and survey. Copeia 1988:719-729.

Simpson, T. H. \& WardLe, C. S. 1967. A seasonal cycle in the testis of the spurdog, Squalus acanthias and the sites of 3ß-hydroxysteroid dehydrogenase activity. Journal of the Marine Biological Association of the United Kingdom 47:699-708.

STANLEY, H. P. 1966. The structure and development of the follicle in Scyliorhinus caniculus and Torpedo marmorata (Elasmobranchii). Zeitschrift für Zellforschung 75:453-468.

Stehmann, M. F. W. 2002. Proposal of a maturity stages scale for oviparous and viviparous cartilaginous fishes (Pisces, Chondrichthyes). Archive of Fishery and Marine Research 50:23-48. 
Sulikowski, J. A.; Kneebone, J.; Elzey, S.; JureK, J. \& Danley, P. 2005. The reproductive cycle of the thorny skate (Amblyraja radiata) in the western Gulf of Maine. Fishery Bulletin 103:536-543.

Sumpter, J. P. \& Dood, J. M. 1979. The annual reproductive cycle of the female lesser spotted dogfish Scyliorhinus canicula L. and its endocrine control. Journal of Fish Biology 15:687-695.

Tamini, L. L.; Chiaramonte, G. E.; Pérez, J. E. \& Cappozzo, H. L. 2006. Batoids in a coastal trawl fishery of Argentina. Fisheries Research 77:326-332.

Teshima, K. 1981. Studies on the reproduction of japanese smooth dogfishes, Mustelus manazo and Mustelus griseus. Journal of Shimonoseki University of Fisheries 29:113-199.
Walker, T. 2005. Reproduction in fisheries Science. In: Hamlett, W. C. ed. Reproductive Biology and Phylogeny of Chondrichthyes. Sharks, Batoids and Chimeras. Enfield, Science Publishers, p.81127.

Ward Paige, C. A.; Keith, D. M.; Worm, B. \& Lotze, K. 2012. Recovery potential and conservation options for elasmobranchs. Journal of Fish Biology 80:1844-1869. 